\title{
Analysis of growth response of cool season cereals "wheat vs. rye" grown in organic and inorganic soils
}

\author{
Amanullah $^{1 *}$, Bobby A. Stewart ${ }^{2}$ \\ ${ }^{1}$ Department of Agronomy, Faculty of Crop Production Sciences, Khyber Pakhtunkhwa Agricultural University, Peshawar-Pakistan-25130 \\ ${ }^{2}$ Dryland Agriculture Institute, West Texas A\&M University, Texas-USA
}

\section{A B S TR A C T}

\begin{abstract}
Plant growth response of wheat (Triticum aestivum L.) vs. rye (Secale cereale L.) to organic and inorganic soils was performed at 30,60 and 90 days after emergence (DAE). A pot experiment was conducted at The Dryland Agriculture Institute, West Texas A\&M University Texas, USA, during winter 2009-2010 using three organic soil mixtures (potting soil/compost) [Miracle Grow (MG), Sunshine Peat Moss (SPM), and Garden Basic Peat Humus (GBPM)], and two inorganic soils [Canyon Soil (CS) and Amarillo Soil (AS)]. The following measurements were performed to quantify plant growth: leaf area plant ${ }^{-1}$ (LAPP), leaf area expansion rate (LER), specific leaf area (SLA), leaf area ratio (LAR), plant height, stem elongation rate (SER), root length (RL), number of roots plant ${ }^{-1}$ (NRPP) number of tillers plant ${ }^{-1}$ (NTPP), stem girth, carbon exchange rate (CER), absolute growth rate (AGR), crop growth rate (CGR), and net assimilation rate (NAR) The experiment was performed in completely randomized design with three replicates. The objective of this experiment was to check whether growth response of wheat vs. rye differ under organic and inorganic soils? The results revealed that both crops responded differently in terms of growth at different crop growth stages under organic and inorganic soils. The planned mean comparison indicated that both wheat and rye grown under organic soils had higher LAPP, LER, SLA, LAR, plant height, SER, root length, NRPP, NTPP, AGR and CGR than crops grown under inorganic soils. Interestingly, the stem girth, CER and NAR declined under organic soils as compared with inorganic soils. The leaf characteristics (LAPP, LER, SLA and LAR) was greater under GBPM > MG > SPM > AS > CS, and rye performed better than wheat at different growth stages. Plant height, SER and root lengths was higher under MG $>$ GBPM $>$ SPM $>$ AS $>$ CS, however no significant differences were found between the two crops at different growth stages. The NRPP and NTPP were more under MG $>$ GBPM $>\mathrm{SPM}>\mathrm{AS}>\mathrm{CS}$, and rye performed better than wheat. The AGR and CGR values were more under MG > GBPM > SPM > AS > CS, rye performance was good at $60 \mathrm{DAE}$, and wheat ranked first at 30 and $90 \mathrm{DAE}$. Both AGR and CGR values were higher at $90>$ $60>30$ DAE indicated increase with the passage of time. The AGR and CGR showed positive relationship with increase in LAPP, LER, plant height, root length, NRPP and NTPP. The shoot to root ratio decreased with the passage of time and showed negative relationship with increase in root length.
\end{abstract}

Keywords: Wheat; Rye; Organic soils; Inorganic soils; Growth analysis; Growth stages

\section{INTRODUCTION}

Organic agriculture is important for the improvement of the environmental conditions and human health (Kurtar and Ayan, 2004; Zengin, 2007). According to Plaster (2009), organic soils contain more than 20 to $30 \%$ organic matter is mostly classified as Histosols. Organic soils having high water holding capacity; hold water about 4 to 5 times of its weight and dries out very slowly than mineral soils. Organic soils are light weight because of the lower bulk density (0.2 to 0.3 ) than mineral soils (1.2 to 1.5$)$. Organic soils generally have very good physical conditions than mineral soils. The organic soils are more porous, open, and easy to cultivate than mineral soils (Cowan, online). Amanullah
(2014) reported that organic soils had more positive effects on the shoot and root development, dry matter portioning and accumulation, and water use efficiency of wheat and rye than inorganic soils.

There is lack of research on crops growth response under organic and inorganic soils. The objective of this study was to study whether different soil types "organic vs. inorganic" influence the growth analysis [leaf area plant ${ }^{-1}$ (LAPP), leaf area expansion rate (LER), specific leaf area (SLA), leaf area ratio (LAR), plant height, stem elongation rate (SER), root length (RL), number of roots plant ${ }^{-1}(\mathrm{NRPP})$ number of tillers plant ${ }^{-1}$ (NTPP), stem girth, carbon exchange rate (CER), absolute growth rate (AGR), crop growth rate

\footnotetext{
*Corresponding author:

Amanullah, Department of Agronomy, Faculty of Crop Production Sciences, Khyber Pakhtunkhwa Agricultural University,

Peshawar-Pakistan-25130. E-mail: amanullah@aup.edu.pk
} 
(CGR), and net assimilation rate (NAR)] of the two winter cereals "wheat vs. rye" at different growth stages or not?

\section{MATERIALS AND METHODS}

Growth analysis [leaf area plant ${ }^{-1}$ (LAPP), leaf area expansion rate (LER), specific leaf area (SLA), leaf area ratio (LAR), plant height, stem elongation rate (SER), root length (RL), number of roots plant ${ }^{-1}(\mathrm{NRPP})$ number of tillers plant ${ }^{-1}$ (NTPP), stem girth, carbon exchange rate (CER), absolute growth rate (AGR), crop growth rate (CGR), and net assimilation rate (NAR)] response of wheat (Triticum aestivum L., cv. 'TAM III') vs. rye (Secale cereale L., cv. 'Elbon') was investigated under three organic soils (potting mix/composts) [Miracle Grow (MG), Sunshine Peat Moss (SPM), and Garden Basic Peat Humus (GBPM)] and two inorganic soils (Canyon soil and Amarillo soil) in pot experiment at Dryland Agriculture Institute, West Texas A\&M University, CS, Texas, USA during winter 2009-10. The experiment was performed in completely randomized design with three repeats.

After one week of emergence 15 plants were maintained per pot, and then five plants were uprooted at 30, 60 and 90 days after emergence (DAE). The root were washed with tap water, and the plants were then divided into three parts i.e. roots, leaves and stems. The materials was put in paper bags and then in oven at $80^{\circ} \mathrm{C}$ for about 20 hours. The samples were weighing by electronic balance (Sartorius Basic, BA2105) and the average data on dry weight of root, leaf, and stem per plant was worked out. Shoot dry weight per plant was obtained by adding leaf dry weight with stem dry weight per plant. The sum of the shoot and root dry weight was called as total dry weight per plant. Plant height (shoot length) and root length was measured in $\mathrm{cm}$ with help of measuring tape. Plant height was divided by root length to get data on shoot-root ratio (by length). The SER (stem elongation rate), LER (leaf area expansion rate), mean single leaf area (MSLA), leaf area plant ${ }^{-1}$ (LAPP), specific leaf area (SLA) and leaf area ratio (LAR) were determined using the following formulae:

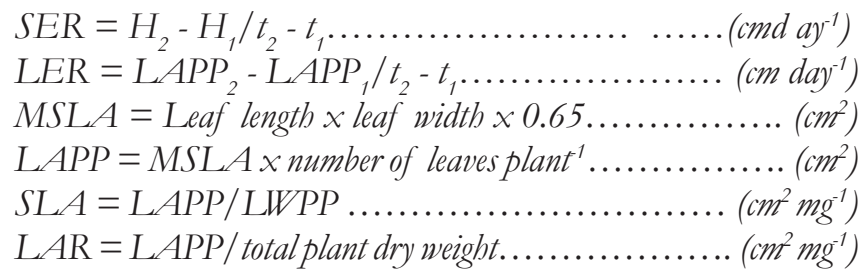

Where:

$\mathrm{H}_{1}=$ Plant height $(\mathrm{cm})$ at the beginning of interval

$\mathrm{H}_{2}=$ Plant height $(\mathrm{cm})$ at the end of interval
$\mathrm{LAPP}_{1}=$ Leaf area per plant $\left(\mathrm{cm}^{2}\right)$ at the beginning of interval

$\mathrm{LAPP}_{2}=$ Leaf area per plant $\left(\mathrm{cm}^{2}\right)$ at the end of interval $\mathrm{t}_{2}-\mathrm{t}_{1}=$ The time interval between the two consecutive samplings

Absolute growth rate (AGR): dry matter accumulation per plant per unit time; crop growth rate (CGR): dry matter accumulation per unit ground area per unit time; and net assimilation rate (NAR): dry matter accumulation per unit leaf area per unit time was determined using the following formulae:

$A G R=W_{2}-W_{1} / t_{2}-t_{1} \ldots \ldots \ldots \ldots \ldots \ldots\left(\right.$ g plant $\left.^{-1} \mathrm{day}^{-1}\right)$ $C G R=W_{2}^{2}-W_{1} /(G A)\left(t_{2}-t_{1}\right) \ldots \ldots \ldots \ldots \ldots \ldots .\left(\mathrm{g} \mathrm{m}^{-2} \mathrm{day}^{-1}\right)$ $N A R=C G R / L A I \ldots \ldots \ldots \ldots \ldots \ldots \ldots \ldots \ldots\left(\mathrm{g} \mathrm{m}^{-2} \mathrm{day}^{-1}\right)$

Where:

$W_{1}=$ Dry weight per plant at the beginning of interval $W_{2}=$ Dry weight per plant at the end of interval

$t_{2}-t_{1}=$ The time interval between the two consecutive samplings

GA = Ground area occupied by plants at each sampling LAI $=$ Leaf area index (leaf area per plant divided by ground area per plant)

\section{Statistical analysis}

Data were subjected to analysis of variance (ANOVA) according to the methods described in Steel and Torrie (1980) and treatment means were compared using the least significant difference (LSD) at $P \leq 0.05$.

\section{RESULTS}

\section{Leaf area plant ${ }^{-1}$}

Leaf area plant ${ }^{-1}$ (LAPP) was calculated as the product of mean single leaf area and number of leaves plant ${ }^{-1}$. Rye produced significantly higher LAPP of $43.8 \mathrm{~cm}^{2}$ than wheat $\left(29.3 \mathrm{~cm}^{2}\right)$ at $30 \mathrm{DAE}$ (Table 1). The highest LAPP $\left(87.2 \mathrm{~cm}^{2}\right)$ was found when crops were grown in GBPH, followed by $81.1 \mathrm{~cm}^{2}$ in MG, and the LAPP of rye was higher than wheat in both GBPH and MG. The minimum LAPP of $1.7 \mathrm{~cm}^{2}$ was recorded when crops were grown in Canyon soil. At 60 DAE, rye had higher LAPP $\left(151.2 \mathrm{~cm}^{2}\right)$ than wheat $\left(101.4 \mathrm{~cm}^{2}\right)$. The highest LAPP $\left(324.1 \mathrm{~cm}^{2}\right)$ was obtained when crops were grown in GBPH, followed by MG $\left(285.5 \mathrm{~cm}^{2}\right)$. In both GBPH and MG, rye had significantly higher LAPP than wheat. The LAPP reduced to minimum in Canyon soil $\left(3.7 \mathrm{~cm}^{2}\right)$, but no significant differences were observed in the LAPP of the two crops. At 90 DAE, rye had relatively higher LAPP $\left(251.7 \mathrm{~cm}^{2}\right)$ than wheat $\left(198.1 \mathrm{~cm}^{2}\right)$. The highest LAPP $\left(470.8 \mathrm{~cm}^{2}\right)$ was noted when crops were grown in GBPH, being at par 
Amanullah and Stewart: Soil types influence growth of wheat and rye

Table 1: Leaf area plant ${ }^{-1}\left(\mathrm{~cm}^{2}\right)$ of wheat vs. rye grown under different soil types

\begin{tabular}{|c|c|c|c|c|c|c|c|c|c|}
\hline \multirow[t]{2}{*}{ Soil types } & \multicolumn{3}{|c|}{30 DAE } & \multicolumn{3}{|c|}{60 DAE } & \multicolumn{3}{|c|}{$90 \mathrm{DAE}$} \\
\hline & Wheat & Rye & Mean & Wheat & Rye & Mean & Wheat & Rye & Mean \\
\hline Canyon (inorganic) & 1.6 & 1.7 & 1.7 & 4.3 & 3.1 & 3.7 & 43.8 & 42.6 & 43.2 \\
\hline Amarillo (inorganic) & 11.7 & 11.8 & 11.7 & 37.6 & 40.2 & 38.9 & 130.9 & 103.2 & 117.1 \\
\hline MG (organic) & 70.3 & 91.8 & 81.1 & 194.6 & 376.4 & 285.5 & 359.4 & 578.3 & 468.9 \\
\hline SPM (organic) & 34.0 & 38.0 & 36.0 & 95.7 & 109.9 & 102.8 & 187.0 & 246.8 & 216.9 \\
\hline GBPH (organic) & 56.8 & 117.5 & 87.2 & 274.3 & 374.0 & 324.1 & 440.4 & 501.1 & 470.8 \\
\hline Mean & 29.3 & 43.8 & & 101.4 & 151.2 & & 198.1 & 251.7 & \\
\hline \multicolumn{10}{|c|}{ Planned mean comparison } \\
\hline Organic soils & 53.7 & 82.4 & 68.1 & 188.2 & 286.8 & 237.5 & 328.9 & 442.1 & 385.5 \\
\hline Inorganic soils & 6.7 & 6.8 & 6.7 & 21.0 & 21.7 & 21.3 & 87.4 & 72.9 & 80.2 \\
\hline \multicolumn{10}{|l|}{ LSD $(P \leq 0.05)$} \\
\hline Crops & 11.31 & & & 25.9 & & & ns & & \\
\hline Soil types & 19.59 & & & 44.8 & & & 106.6 & & \\
\hline Interaction & 27.70 & & & 63.3 & & & ns & & \\
\hline
\end{tabular}

Where: DAE=Days after emergence, MG=Miracle grow, SPM=Sunshine peat moss, GBPH=Garden basic peat humus, ns=Non-significant data, and LSD=Least significant difference

with MG (468.9 $\mathrm{cm}^{2}$ ), and the LAPP of rye was higher than wheat in both soils. The planned mean comparison indicated that crops grown under organic soils produced higher LAPP than crops grown under inorganic soils. The LAPP was higher at 90 DAE than at 30 and 60 DAE $(90>60>30$ DAE).

\section{Leaf area expansion rate}

Leaf area expansion rate (LER) was calculated as LAPP divided by number of days taken. The LER of rye $\left(1.459 \mathrm{~cm}^{2}\right.$ plant ${ }^{-1}$ day $\left.^{-1}\right)$ was significantly $(P \leq 0.05)$ higher than wheat $\left(0.977 \mathrm{~cm}^{2}\right.$ plant $^{-1}$ day $\left.^{-1}\right)$ at $30 \mathrm{DAE}$ (Table 2). The highest LER $\left(2.905 \mathrm{~cm}^{2}\right.$ plant $\left.^{-1} \mathrm{day}^{-1}\right)$ was calculated when crops were grown in GBPH, being at par with MG $\left(2.702 \mathrm{~cm}^{2}\right.$ plant $\left.^{-1} \mathrm{day}^{-1}\right)$, and the LER of rye was higher than wheat in both GBPH and MG. The minimum LER $\left(0.055 \mathrm{~cm}^{2}\right.$ plant $^{-1}$ day $\left.^{-1}\right)$ was recorded when crops were grown in Canyon soil. At 60 DAE, rye had higher LER $\left(2.52 \mathrm{~cm}^{2}\right.$ plant $^{-1}$ day $\left.^{-1}\right)$ than wheat $\left(1.69 \mathrm{~m}^{2}\right.$ plant $^{-1}$ day $\left.^{-1}\right)$. The highest LER $\left(5.40 \mathrm{~cm}^{2}\right.$ plant $\left.^{-1} \mathrm{day}^{-1}\right)$ was noted when crops were grown in GBPH, being at par with MG $\left(4.76 \mathrm{~cm}^{2}\right.$ plant $\left.{ }^{-1} \mathrm{day}^{-1}\right)$. In both GBPH and MG, rye had significantly higher LER than wheat. The LER reduced to minimum in Canyon soil $\left(0.06 \mathrm{~cm}^{2}\right.$ plant $\left.{ }^{-1} \mathrm{day}^{-1}\right)$, but no significant differences were observed in the LER of the two crops. At 90 DAE, rye had relatively higher LER (2.80 $\mathrm{cm}^{2}$ plant ${ }^{-1}$ day $\left.^{-1}\right)$ than wheat $\left(2.20 \mathrm{~cm}^{2}\right.$ plant $^{-1}$ day $\left.^{-1}\right)$. The highest LER $\left(5.23 \mathrm{~cm}^{2}\right.$ plant $^{-1}$ day $\left.^{-1}\right)$ was noted when crops were grown in GBPH, being at par with $M G\left(5.21 \mathrm{~cm}^{2}\right.$ plant $^{-1}$ day $\left.^{-1}\right)$, and the LER of rye was higher than wheat in both soils. The LER reduced to minimum in Canyon soil $\left(0.48 \mathrm{~cm}^{2}\right.$ plant $^{-1}$ day $\left.^{-1}\right)$; however, there was no difference in LER of wheat and rye. The planned mean comparison indicated that crops grown under organic soils produced higher LER than crops grown under inorganic soils. The LER was higher at $90 \mathrm{DAE}$ than at 30 and $60 \mathrm{DAE}(90>$ $60>30$ DAE).

\section{Specific leaf area}

Specific leaf area (SLA) was calculated as leaf area plant ${ }^{-1}$ divided by leaf dry weight plant ${ }^{-1}$. According to Craufurd et al. (1999), plants with higher SLA (thicker leaves) usually have higher densities of chlorophyll per unit area, and hence have greater photosynthetic capacities than thinner leaves. The SLA of rye was higher $\left(1.28 \mathrm{~cm}^{2} \mathrm{mg}^{-1}\right)$ than wheat $\left(0.76 \mathrm{~cm}^{2} \mathrm{mg}^{-1}\right)$ at $30 \mathrm{DAE}$ (Table 3). The highest SLA $\left(2.26 \mathrm{~cm}^{2} \mathrm{mg}^{-1}\right)$ was calculated when crops were grown in GBPH, followed by MG $\left(1.63 \mathrm{~cm}^{2} \mathrm{mg}^{-1}\right)$, and the SLA of rye was higher than wheat in both GBPH and MG. The minimum SLA of $0.19 \mathrm{~cm}^{2} \mathrm{mg}^{-1}$ was recorded when crops were grown in Canyon soil. At $60 \mathrm{DAE}$, rye had relatively higher SLA $\left(0.51 \mathrm{~cm}^{2} \mathrm{mg}^{-1}\right)$ than wheat $\left(0.44 \mathrm{~cm}^{2} \mathrm{mg}^{-1}\right)$. The highest SLA $\left(0.85 \mathrm{~cm}^{2} \mathrm{mg}^{-1}\right)$ was obtained when crops were grown in GBPH, followed by MG $\left(0.68 \mathrm{~cm}^{2} \mathrm{mg}^{-1}\right)$. In GBPH and MG, rye had relatively higher SLA than wheat. The SLA reduced to minimum of $0.15 \mathrm{~cm}^{2} \mathrm{mg}^{-1}$ in Canyon soil, no significant differences were observed in the SLA of the two crops. At 90 DAE, rye had higher SLA (0.69 $\left.\mathrm{cm}^{2} \mathrm{mg}^{-1}\right)$ than wheat $\left(0.40 \mathrm{~cm}^{2} \mathrm{mg}^{-1}\right)$. The highest SLA $\left(0.98 \mathrm{~cm}^{2} \mathrm{mg}^{-1}\right)$ was calculated when crops were grown in SPM, followed by GBPH $\left(0.55 \mathrm{~cm}^{2} \mathrm{mg}^{-1}\right)$, and the SLA of rye was relatively higher than wheat in both soils. The SLA reduced to minimum $\left(0.33 \mathrm{~cm}^{2} \mathrm{mg}^{-1}\right)$ when crops were grown in Canyon soil; however, there was no difference in SLA of wheat and rye when grown under Canyon soil. The planned mean comparison indicated that crops grown under organic soils produced higher SLA than crops grown under inorganic soils. The SLA was higher at 30 DAE than at 60 and 90 DAE.

\section{Leaf area ratio}

Leaf area ratio (LAR) was calculated as leaf area plant ${ }^{-1}$ divided by total dry weight plant ${ }^{-1}$. The LAR of rye was higher $\left(0.74 \mathrm{~cm}^{2} \mathrm{mg}^{-1}\right)$ than wheat $\left(0.43 \mathrm{~cm}^{2} \mathrm{mg}^{-1}\right)$ at 30 DAE (Table 4). The highest LAR $\left(1.38 \mathrm{~cm}^{2} \mathrm{mg}^{-1}\right)$ was 
Table 2: Leaf area expansion rate $\left(\mathrm{cm}^{2}\right.$ plant $^{-1}$ day $\left.^{-1}\right)$ of wheat vs. rye grown under different soil types

\begin{tabular}{|c|c|c|c|c|c|c|c|c|c|}
\hline \multirow[t]{2}{*}{ Soil types } & \multicolumn{3}{|c|}{$30 \mathrm{DAE}$} & \multicolumn{3}{|c|}{60 DAE } & \multicolumn{3}{|c|}{90 DAE } \\
\hline & Wheat & Rye & Mean & Wheat & Rye & Mean & Wheat & Rye & Mean \\
\hline Canyon (inorganic) & 0.053 & 0.057 & 0.055 & 0.07 & 0.05 & 0.06 & 0.49 & 0.47 & 0.48 \\
\hline Amarillo (inorganic) & 0.390 & 0.392 & 0.391 & 0.63 & 0.67 & 0.65 & 1.45 & 1.15 & 1.30 \\
\hline MG (organic) & 2.345 & 3.059 & 2.702 & 3.24 & 6.27 & 4.76 & 3.99 & 6.43 & 5.21 \\
\hline SPM (organic) & 1.134 & 1.268 & 1.201 & 1.60 & 1.83 & 1.71 & 2.08 & 2.74 & 2.41 \\
\hline GBPH (organic) & 1.893 & 3.917 & 2.905 & 4.57 & 6.23 & 5.40 & 4.89 & 5.57 & 5.23 \\
\hline Mean & 0.98 & 1.46 & & 1.69 & 2.52 & & 2.20 & 2.80 & \\
\hline \multicolumn{10}{|c|}{ Planned mean comparison } \\
\hline Organic soils & 1.79 & 2.75 & 2.27 & 3.14 & 4.78 & 3.96 & 3.65 & 4.91 & 4.28 \\
\hline Inorganic soils & 0.22 & 0.22 & 0.22 & 0.35 & 0.36 & 0.36 & 0.97 & 0.81 & 0.89 \\
\hline \multicolumn{10}{|l|}{ LSD $(P \leq 0.05)$} \\
\hline Crops & 0.377 & & & 0.43 & & & ns & & \\
\hline Soil types & 0.653 & & & 0.75 & & & 1.18 & & \\
\hline Interaction & 0.923 & & & 1.06 & & & ns & & \\
\hline
\end{tabular}

Where: DAE=Days after emergence, MG=Miracle grow, SPM=Sunshine peat moss, GBPH=Garden basic peat humus, ns=Non-significant data, and LSD=Least significant difference

Table 3: Specific leaf area $\left(\mathrm{cm}^{2} \mathrm{mg}^{-1}\right)$ of wheat vs. rye grown under different soil types

\begin{tabular}{|c|c|c|c|c|c|c|c|c|c|}
\hline \multirow[t]{2}{*}{ Soil types } & \multicolumn{3}{|c|}{30 DAE } & \multicolumn{3}{|c|}{$60 \mathrm{DAE}$} & \multicolumn{3}{|c|}{$90 \mathrm{DAE}$} \\
\hline & Wheat & Rye & Mean & Wheat & Rye & Mean & Wheat & Rye & Mean \\
\hline Canyon (inorganic) & 0.16 & 0.22 & 0.19 & 0.17 & 0.13 & 0.15 & 0.15 & 0.51 & 0.33 \\
\hline Amarillo (inorganic) & 0.72 & 0.70 & 0.71 & 0.46 & 0.62 & 0.54 & 0.25 & 0.59 & 0.42 \\
\hline MG (organic) & 1.17 & 2.10 & 1.63 & 0.55 & 0.80 & 0.68 & 0.35 & 0.59 & 0.47 \\
\hline SPM (organic) & 0.91 & 1.33 & 1.12 & 0.46 & 0.54 & 0.50 & 0.68 & 1.28 & 0.98 \\
\hline GBPH (organic) & 1.40 & 3.12 & 2.26 & 0.87 & 0.82 & 0.85 & 0.54 & 0.56 & 0.55 \\
\hline Mean & 0.76 & 1.28 & & 0.44 & 0.51 & & 0.40 & 0.69 & \\
\hline \multicolumn{10}{|c|}{ Planned mean comparison } \\
\hline Organic soils & 1.16 & 2.18 & 1.67 & 0.63 & 0.72 & 0.68 & 0.52 & 0.81 & 0.67 \\
\hline Inorganic soils & 0.44 & 0.46 & 0.45 & 0.32 & 0.38 & 0.35 & 0.20 & 0.55 & 0.38 \\
\hline \multicolumn{10}{|l|}{$\operatorname{LSD}(P \leq 0.05)$} \\
\hline Crops & 0.34 & & & ns & & & 0.14 & & \\
\hline Soil types & 0.58 & & & 0.16 & & & 0.24 & & \\
\hline Interaction & 0.83 & & & ns & & & ns & & \\
\hline
\end{tabular}

Where: DAE=Days after emergence, MG=Miracle grow, SPM=Sunshine peat moss, GBPH=Garden basic peat humus, ns=Non-significant data, and LSD=Least significant difference

calculated when crops were grown in GBPH, followed by MG $\left(0.93 \mathrm{~cm}^{2} \mathrm{mg}^{-1}\right)$, and the LAR of rye was higher than wheat in both GBPH and MG. The minimum LAR $\left(0.07 \mathrm{~cm}^{2} \mathrm{mg}^{-1}\right)$ was recorded when crops were grown in Canyon soil. At 60 DAE, rye had higher LAR $\left(0.28 \mathrm{~cm}^{2}\right.$ $\left.\mathrm{mg}^{-1}\right)$ than wheat $\left(0.23 \mathrm{~cm}^{2} \mathrm{~g}^{-1}\right)$. The highest LAR $\left(0.50 \mathrm{~cm}^{2}\right.$ $\mathrm{mg}^{-1}$ ) was obtained when crops were grown in GBPH, followed by MG $\left(0.40 \mathrm{~cm}^{2} \mathrm{mg}^{-1}\right)$. In GBPH and MG, rye had relatively higher LAR than wheat. The LAR of crops reduced to minimum $\left(0.05 \mathrm{~cm}^{2} \mathrm{mg}^{-1}\right)$ when grown in Canyon soil, but no significant differences were observed in the LAR of the two crops. At 90 DAE, rye had higher LAR $\left(0.31 \mathrm{~cm}^{2} \mathrm{mg}^{-1}\right)$ than wheat $\left(0.19 \mathrm{~cm}^{2} \mathrm{mg}^{-1}\right)$. The highest LAR $\left(0.42 \mathrm{~cm}^{2} \mathrm{mg}^{-1}\right)$ was calculated when crops were grown in SPM, and the LAR of rye was relatively higher than wheat crop. The LAR reduced to minimum $\left(0.17 \mathrm{~cm}^{2}\right.$ $\mathrm{mg}^{-1}$ ) each in Canyon soil and MG; and the LAR of rye was higher than wheat in the two soils. The planned mean comparison indicated that crops grown under organic soils produced higher LAR than crops grown under inorganic soils. The LAR was higher at $30 \mathrm{DAE}$ than at 60 and 90 DAE.

\section{Plant height}

There was no significant $(P \leq 0.05)$ difference in heights of wheat and rye at 30 days after emergence (DAE) as shown in Table 5. Among the soil types, tallest plants $(34.8 \mathrm{~cm})$ were produced when crops were grown in miracle grow (MG) being at par with $33.7 \mathrm{~cm}$ heights recorded in garden basic peat humus (GBPH), and the heights of rye was higher than wheat in both soil. At second cut (60 DAE), there was no significant difference in heights of wheat and rye. Among the soil types, tallest plants $(41.0 \mathrm{~cm})$ were produced when crops were grown in MG, followed by $38.8 \mathrm{~cm}$ in GBPH, and the heights of rye was higher than wheat in both soils. At third cut (90 DAE), there was no significant difference in heights of wheat and rye. Tallest plants $(51.2 \mathrm{~cm})$ were produced when crops were grown in GBPH, being at par with $\mathrm{MG}(50.0 \mathrm{~cm})$, and the height of rye was higher than wheat in both soils. The planned mean comparison indicated 
that crops grown under organic soils produced taller plants than crops grown under inorganic soils. The plant heights increased with passage of time $(90>60>30 \mathrm{DAE})$.

\section{Stem elongation rate}

Stem elongation rate (SER) was calculated as plant height divided by number days taken. There were no significant differences in stem elongation rate (SER) of wheat $\left(0.77 \mathrm{~cm} \mathrm{day}^{-1}\right)$ and rye $\left(0.75 \mathrm{~cm} \mathrm{day}^{-1}\right)$ at $30 \mathrm{DAE}$ (Table 6). The highest SER $\left(1.16 \mathrm{~cm} \mathrm{day}^{-1}\right)$ was calculated when crops were grown in MG, being at par with GBPH $\left(1.12 \mathrm{~cm} \mathrm{day}^{-1}\right)$, and the SER of rye was higher than wheat in both MG and GPM. At 60 DAE, there were no significant differences in SER of wheat and rye $(0.47 \mathrm{~cm}$ day $^{-1}$ each $)$. The highest SER $\left(0.68 \mathrm{~cm} \mathrm{day}^{-1}\right)$ was recorded when crops were grown in $\mathrm{MG}$, being at par with GBPH $\left(0.65 \mathrm{~cm} \mathrm{day}^{-1}\right)$, and the SER of rye was higher than wheat in both soils. At $90 \mathrm{DAE}$, there was also no significant difference in SER of wheat and rye. The highest SER $\left(0.57 \mathrm{~cm} \mathrm{day}^{-1} \mathrm{~cm}\right)$ was noted when crops were grown in
GBPH, being at par with MG $\left(0.56 \mathrm{~cm}\right.$ day $\left.^{-1}\right)$, and the SER of rye was relatively higher than wheat in both GBPH and MG. The planned mean comparison indicated that crops grown under organic soils had higher SER than crops grown under inorganic soils. The SER in contrast to plant height, decreased with passage of time $(30>60$ $>90$ DAE).

\section{Root length}

There were no significant differences in the root length of wheat and rye at 30,60 and 90 DAE (Table 7). At 30 DAE, longer roots $(15.3 \mathrm{~cm})$ were produced when crops were grown in MG, being at par with SPM $(14.2 \mathrm{~cm})$, however, in $M G$, rye roots were significantly longer than that of wheat; incontrast, wheat roots were significantly longer than rye when grown in SPM. At $60 \mathrm{DAE}$, longer roots $(18.5 \mathrm{~cm})$ were recorded when crops were grown in $\mathrm{MG}$, being at par with SPM $(17.5 \mathrm{~cm}$, and the rye roots were longer $(19.3 \mathrm{~cm})$ than wheat $(17.7 \mathrm{~cm})$ when grown in $M G$, in contrast, wheat roots were longer $(18.7 \mathrm{~cm})$ than rye

Table 4: Leaf area ratio $\left(\mathrm{cm}^{2} \mathrm{mg}^{-1}\right)$ of wheat vs. rye grown under different soil types

\begin{tabular}{|c|c|c|c|c|c|c|c|c|c|}
\hline \multirow[t]{2}{*}{ Soil types } & \multicolumn{3}{|c|}{$30 \mathrm{DAE}$} & \multicolumn{3}{|c|}{$60 \mathrm{DAE}$} & \multicolumn{3}{|c|}{$90 \mathrm{DAE}$} \\
\hline & Wheat & Rye & Mean & Wheat & Rye & Mean & Wheat & Rye & Mean \\
\hline Canyon (inorganic) & 0.07 & 0.07 & 0.07 & 0.06 & 0.04 & 0.05 & 0.09 & 0.24 & 0.17 \\
\hline Amarillo (inorganic) & 0.37 & 0.36 & 0.36 & 0.18 & 0.25 & 0.21 & 0.12 & 0.29 & 0.21 \\
\hline MG (organic) & 0.68 & 1.17 & 0.93 & 0.32 & 0.49 & 0.40 & 0.12 & 0.22 & 0.17 \\
\hline SPM (organic) & 0.56 & 0.81 & 0.69 & 0.28 & 0.36 & 0.32 & 0.31 & 0.54 & 0.42 \\
\hline GBPH (organic) & 0.82 & 1.94 & 1.38 & 0.50 & 0.51 & 0.50 & 0.21 & 0.27 & 0.24 \\
\hline Mean & 0.43 & 0.74 & & 0.23 & 0.28 & & 0.19 & 0.31 & \\
\hline \multicolumn{10}{|c|}{ Planned mean comparison } \\
\hline Organic soils & 0.69 & 1.31 & 1.00 & 0.37 & 0.45 & 0.41 & 0.21 & 0.34 & 0.28 \\
\hline Inorganic soils & 0.22 & 0.22 & 0.22 & 0.12 & 0.15 & 0.13 & 0.11 & 0.27 & 0.19 \\
\hline \multicolumn{10}{|l|}{ LSD $(P \leq 0.05)$} \\
\hline Crops & 0.18 & & & 0.05 & & & 0.06 & & \\
\hline Soil types & 0.32 & & & 0.09 & & & 0.10 & & \\
\hline Interaction & 0.45 & & & ns & & & ns & & \\
\hline
\end{tabular}

Where: DAE=Days after emergence, MG=Miracle grow, SPM=Sunshine peat moss, GBPH=Garden basic peat humus, ns=Non-significant data, and LSD=Least significant difference

Table 5: Plant height $(\mathrm{cm})$ of wheat vs. rye grown under different soil types

\begin{tabular}{|c|c|c|c|c|c|c|c|c|c|}
\hline \multirow[t]{2}{*}{ Soil types } & \multicolumn{3}{|c|}{$30 \mathrm{DAE}$} & \multicolumn{3}{|c|}{$60 \mathrm{DAE}$} & \multicolumn{3}{|c|}{$90 \mathrm{DAE}$} \\
\hline & Wheat & Rye & Mean & Wheat & Rye & Mean & Wheat & Rye & Mean \\
\hline Canyon (inorganic) & 12.7 & 12.3 & 12.5 & 16.0 & 17.3 & 16.7 & 32.0 & 29.7 & 30.8 \\
\hline Amarillo (inorganic) & 20.0 & 16.0 & 18.0 & 28.3 & 23.3 & 25.8 & 39.3 & 34.0 & 36.7 \\
\hline MG (organic) & 33.7 & 36.0 & 34.8 & 40.3 & 41.7 & 41.0 & 49.7 & 50.3 & 50.0 \\
\hline SPM (organic) & 31.7 & 28.0 & 29.8 & 35.7 & 32.7 & 34.2 & 41.3 & 39.3 & 40.3 \\
\hline GBPH (organic) & 32.7 & 34.7 & 33.7 & 37.3 & 40.3 & 38.8 & 49.7 & 52.7 & 51.2 \\
\hline Mean & 23.2 & 22.6 & & 28.3 & 28.3 & & 38.2 & 38.8 & \\
\hline \multicolumn{10}{|c|}{ Planned mean comparison } \\
\hline Organic soils & 32.7 & 32.9 & 32.8 & 37.8 & 38.2 & 38.0 & 46.9 & 47.4 & 47.2 \\
\hline Inorganic soils & 16.4 & 14.2 & 15.3 & 22.2 & 20.3 & 21.3 & 35.7 & 31.9 & 33.8 \\
\hline \multicolumn{10}{|l|}{$\operatorname{LSD}(P \leq 0.05)$} \\
\hline Crops & ns & & & ns & & & ns & & \\
\hline Soil types & 1.49 & & & 2.2 & & & 3.1 & & \\
\hline Interaction & 2.10 & & & 3.1 & & & 4.4 & & \\
\hline
\end{tabular}

Where: DAE=Days after emergence, MG=Miracle grow, SPM=Sunshine peat moss, GBPH=Garden basic peat humus, ns=Non-significant data, and LSD=Least significant difference 
$(17.7 \mathrm{~cm})$ when grown in SPM. At $90 \mathrm{DAE}$, longer roots $(34.0 \mathrm{~cm})$ were produced by the crops when grown in SPM, followed by MG $(26.7 \mathrm{~cm})$, and rye roots were relatively longer than wheat in both SPM and MG. The planned mean comparison indicated that crops grown under organic soils produced longer roots than crops grown under inorganic soils. The root lengths increased with the passage of time $(90>60>30$ DAE $)$.

\section{Shoot root ratio (plant height $\div$ root length)}

There was no significant difference in shoot: root of wheat (3.2) and rye (3.0) at $30 \mathrm{DAE}(\mathrm{P} \leq 0.05)$ shown in Table 8. Among soil types, the highest shoot: root (4.0) was calculated when crops were grown in Canyon soil, followed by 3.7 in Amarillo soils, and the shoot: root of wheat was relatively higher than rye in both soils. The minimum shoot: root (2.1) was recorded when crops were grown in SPM, being at par with MG (2.3). At second cut, there was no significant difference in shoot: root of wheat (2.6) and rye (2.4). Among soil types, the highest shoot: root
(3.5) was obtained when crops were grown in Amarillo soil, followed by GBPH (2.7). In Amarillo soil wheat had higher shoot: root of 4.0 than rye (2.9), but in GBPG rye had higher shoot: root (3.0) than wheat (2.5). The shoot: root reduced to minimum (2.0) when crops were grown in SPM, but no significant differences were observed in the shoot: root of the two crops under SPM. At third cut $(90$ DAE), rye had relatively higher shoot: root (2.1) than rye (1.9). Among soil types, the highest shoot: root (2.6) was obtained when crops were grown in GBPH, and the shoot: root of rye (2.9) was significantly higher than wheat (2.3) under GBPH. The shoot: root reduced to minimum (1.2) when crops were grown in SPM; however, there was no difference in shoot: root of wheat and rye when grown under SPM.

\section{Number of roots plant ${ }^{-1}$}

Number of roots plant ${ }^{-1}$ (NRPP) of rye were more (6.1) than wheat (5.2) at 30 DAE (Table 9). The highest NRPP (10.8) was calculated when crops were grown in GBPH,

Table 6: Stem elongation rate (cm day ${ }^{-1}$ of wheat vs. rye grown under different soil types

\begin{tabular}{|c|c|c|c|c|c|c|c|c|c|}
\hline \multirow[t]{2}{*}{ Soil types } & \multicolumn{3}{|c|}{$30 \mathrm{DAE}$} & \multicolumn{3}{|c|}{$60 \mathrm{DAE}$} & \multicolumn{3}{|c|}{$90 \mathrm{DAE}$} \\
\hline & Wheat & Rye & Mean & Wheat & Rye & Mean & Wheat & Rye & Mean \\
\hline Canyon (inorganic) & 0.42 & 0.41 & 0.42 & 0.27 & 0.29 & 0.28 & 0.36 & 0.33 & 0.34 \\
\hline Amarillo (inorganic) & 0.67 & 0.53 & 0.60 & 0.47 & 0.39 & 0.43 & 0.44 & 0.38 & 0.41 \\
\hline MG (organic) & 1.12 & 1.20 & 1.16 & 0.67 & 0.69 & 0.68 & 0.55 & 0.56 & 0.56 \\
\hline SPM (organic) & 1.06 & 0.93 & 0.99 & 0.59 & 0.54 & 0.57 & 0.46 & 0.44 & 0.45 \\
\hline GBPH (organic) & 1.09 & 1.16 & 1.12 & 0.62 & 0.67 & 0.65 & 0.55 & 0.59 & 0.57 \\
\hline Mean & 0.77 & 0.75 & & 0.47 & 0.47 & & 0.42 & 0.43 & \\
\hline \multicolumn{10}{|c|}{ Planned mean comparison } \\
\hline Organic soils & 1.09 & 1.10 & 1.09 & 0.63 & 0.63 & 0.63 & 0.52 & 0.53 & 0.53 \\
\hline Inorganic soils & 0.55 & 0.47 & 0.51 & 0.37 & 0.34 & 0.36 & 0.40 & 0.36 & 0.38 \\
\hline \multicolumn{10}{|l|}{$\operatorname{LSD}(P \leq 0.05)$} \\
\hline Crops & ns & & & ns & & & ns & & \\
\hline Soil types & 0.05 & & & 0.04 & & & 0.03 & & \\
\hline Interaction & 0.07 & & & 0.05 & & & 0.05 & & \\
\hline
\end{tabular}

Where: DAE=Days after emergence, MG=Miracle grow, SPM=Sunshine peat moss, GBPH=Garden basic peat humus, ns=Non-significant data, and LSD=Least significant difference

Table 7: Root length $(\mathrm{cm})$ of wheat vs. rye grown under different soil types

\begin{tabular}{|c|c|c|c|c|c|c|c|c|c|}
\hline \multirow[t]{2}{*}{ Soil types } & \multicolumn{3}{|c|}{$30 \mathrm{DAE}$} & \multicolumn{3}{|c|}{$60 \mathrm{DAE}$} & \multicolumn{3}{|c|}{$90 \mathrm{DAE}$} \\
\hline & Wheat & Rye & Mean & Wheat & Rye & Mean & Wheat & Rye & Mean \\
\hline Canyon (inorganic) & 3.0 & 3.3 & 3.2 & 7.0 & 7.7 & 7.3 & 15.0 & 13.0 & 14.0 \\
\hline Amarillo (inorganic) & 4.7 & 5.3 & 5.0 & 7.0 & 8.0 & 7.5 & 17.0 & 14.7 & 15.8 \\
\hline MG (organic) & 14.3 & 16.3 & 15.3 & 17.7 & 19.3 & 18.5 & 26.3 & 27.0 & 26.7 \\
\hline SPM (organic) & 15.0 & 13.3 & 14.2 & 18.7 & 16.3 & 17.5 & 33.3 & 34.7 & 34.0 \\
\hline GBPH (organic) & 12.3 & 11.0 & 11.7 & 15.3 & 13.3 & 14.3 & 22.0 & 18.5 & 20.3 \\
\hline Mean & 8.6 & 8.7 & & 11.8 & 11.9 & & 20.9 & 20.1 & \\
\hline \multicolumn{10}{|c|}{ Planned mean comparison } \\
\hline Organic soils & 13.9 & 13.5 & 13.7 & 17.2 & 16.3 & 16.8 & 27.2 & 26.7 & 27.0 \\
\hline Inorganic soils & 3.9 & 4.3 & 4.1 & 7.0 & 7.9 & 7.4 & 16.0 & 13.9 & 14.9 \\
\hline \multicolumn{10}{|l|}{ LSD $(P \leq 0.05)$} \\
\hline Crops & ns & & & ns & & & ns & & \\
\hline Soil types & 1.14 & & & 1.6 & & & 1.9 & & \\
\hline Interaction & 1.61 & & & 2.3 & & & ns & & \\
\hline
\end{tabular}


followed by 7.7 in MG, and the NRPP of rye (11.7) were

higher than wheat (10.0) in GBPH. The minimum NRPP was reported in Canyon soil (2.5). At 60 DAE, rye had higher NRPP (9.6) than wheat (7.6). The highest NRPP

Table 8: Shoot to root ratio (by length) of wheat vs. rye grown under different soil types

\begin{tabular}{|c|c|c|c|c|c|c|c|c|c|}
\hline \multirow[t]{2}{*}{ Soil types } & \multicolumn{3}{|c|}{$30 \mathrm{DAE}$} & \multicolumn{3}{|c|}{$60 \mathrm{DAE}$} & \multicolumn{3}{|c|}{90 DAE } \\
\hline & Wheat & Rye & Mean & Wheat & Rye & Mean & Wheat & Rye & Mean \\
\hline Canyon (inorganic) & 4.2 & 3.8 & 4.0 & 2.3 & 2.3 & 2.3 & 2.2 & 2.3 & 2.2 \\
\hline Amarillo (inorganic) & 4.3 & 3.1 & 3.7 & 4.0 & 2.9 & 3.5 & 2.3 & 2.3 & 2.3 \\
\hline MG (organic) & 2.4 & 2.2 & 2.3 & 2.3 & 2.2 & 2.2 & 1.9 & 1.9 & 1.9 \\
\hline SPM (organic) & 2.1 & 2.1 & 2.1 & 1.9 & 2.0 & 2.0 & 1.2 & 1.1 & 1.2 \\
\hline GBPH (organic) & 2.7 & 3.2 & 2.9 & 2.5 & 3.0 & 2.7 & 2.3 & 2.9 & 2.6 \\
\hline Mean & 3.2 & 3.0 & & 2.6 & 2.4 & & 1.9 & 2.1 & \\
\hline \multicolumn{10}{|c|}{ Planned mean comparison } \\
\hline Organic soils & 2.4 & 2.5 & 2.4 & 2.2 & 2.4 & 2.3 & 1.8 & 2.0 & 1.9 \\
\hline Inorganic soils & 4.3 & 3.5 & 3.9 & 3.2 & 2.6 & 2.9 & 2.3 & 2.3 & 2.3 \\
\hline \multicolumn{10}{|l|}{$\operatorname{LSD}(P \leq 0.05)$} \\
\hline Crops & ns & & & ns & & & ns & & \\
\hline Soil types & 0.7 & & & 0.3 & & & 0.3 & & \\
\hline Interaction & ns & & & 0.5 & & & 0.4 & & \\
\hline
\end{tabular}

Where: $\mathrm{DAE}=$ Days after emergence, MG=Miracle grow, SPM=Sunshine peat moss, GBPH=Garden basic peat humus, ns=Non-significant data, and LSD=Least significant difference

Table 9: Roots plant ${ }^{-1}$ (number) of wheat vs. rye grown under different soil types

\begin{tabular}{|c|c|c|c|c|c|c|c|c|c|}
\hline \multirow[t]{2}{*}{ Soil types } & \multicolumn{3}{|c|}{$30 \mathrm{DAE}$} & \multicolumn{3}{|c|}{$60 \mathrm{DAE}$} & \multicolumn{3}{|c|}{$90 \mathrm{DAE}$} \\
\hline & Wheat & Rye & Mean & Wheat & Rye & Mean & Wheat & Rye & Mean \\
\hline Canyon (inorganic) & 2.0 & 3.0 & 2.5 & 2.5 & 3.5 & 3.0 & 7.0 & 5.0 & 6.0 \\
\hline Amarillo (inorganic) & 4.3 & 5.3 & 4.8 & 7.0 & 8.0 & 7.5 & 10.7 & 7.0 & 8.8 \\
\hline MG (organic) & 6.7 & 8.7 & 7.7 & 11.5 & 17.0 & 14.3 & 25.3 & 20.4 & 22.9 \\
\hline SPM (organic) & 5.7 & 5.3 & 5.5 & 8.0 & 8.0 & 8.0 & 18.3 & 15.3 & 16.8 \\
\hline GBPH (organic) & 10.0 & 11.7 & 10.8 & 13.7 & 18.0 & 15.8 & 24.0 & 17.2 & 20.6 \\
\hline Mean & 5.2 & 6.1 & & 7.6 & 9.6 & & 15.0 & 11.6 & \\
\hline \multicolumn{10}{|c|}{ Planned mean comparison } \\
\hline Organic soils & 7.5 & 8.6 & 8.0 & 11.1 & 14.3 & 12.7 & 22.5 & 17.6 & 20.1 \\
\hline Inorganic soils & 3.2 & 4.2 & 3.7 & 4.8 & 5.8 & 5.3 & 8.9 & 6.0 & 7.4 \\
\hline \multicolumn{10}{|l|}{$\operatorname{LSD}(P \leq 0.05)$} \\
\hline Crops & 0.4 & & & 0.6 & & & ns & & \\
\hline Soil types & 0.7 & & & 1.0 & & & 8.4 & & \\
\hline Interaction & 1.0 & & & 1.5 & & & ns & & \\
\hline
\end{tabular}

Where: DAE=Days after emergence, MG=Miracle grow, SPM=Sunshine peat moss, GBPH=Garden basic peat humus, ns=Non-significant data, and LSD=Least significant difference

Table 10: Tillers plant ${ }^{-1}$, girth $(\mathrm{mm})$ and carbon exchange rate (CER) of wheat vs. rye grown under different soil types after 90 days of emergence

\begin{tabular}{|c|c|c|c|c|c|c|c|c|c|}
\hline \multirow[t]{2}{*}{ Soil Types } & \multicolumn{3}{|c|}{ Tillers plant $^{-1}$} & \multicolumn{3}{|c|}{ Stem girth $(\mathrm{mm})$} & \multicolumn{3}{|c|}{ CER $\left(\mathrm{mmol} \mathrm{m} \mathrm{m}^{-2} \mathrm{~s}^{-1}\right)$} \\
\hline & Wheat & Rye & Mean & Wheat & Rye & Mean & Wheat & Rye & Mean \\
\hline Canyon (inorganic) & 2.00 & 2.67 & 2.33 & 2.18 & 2.00 & 2.09 & 67.90 & 41.73 & 54.82 \\
\hline Amarillo (inorganic) & 3.00 & 3.33 & 3.17 & 3.12 & 2.23 & 2.68 & 45.77 & 134.27 & 90.02 \\
\hline MG (organic) & 4.67 & 13.33 & 9.00 & 2.90 & 2.20 & 2.55 & 16.27 & 23.80 & 20.03 \\
\hline SPM (organic) & 3.67 & 7.00 & 5.33 & 2.34 & 1.42 & 1.88 & 14.03 & 38.73 & 26.38 \\
\hline GBPH (organic) & 5.67 & 11.67 & 8.67 & 2.45 & 1.79 & 2.12 & 23.73 & 32.87 & 28.30 \\
\hline Mean & 3.50 & 6.78 & & 2.38 & 1.79 & & 32.99 & 48.30 & \\
\hline \multicolumn{10}{|c|}{ Planned mean comparison } \\
\hline Organic soils & 4.67 & 10.67 & 7.67 & 2.56 & 1.80 & 2.18 & 18.01 & 31.80 & 24.90 \\
\hline Inorganic soils & 2.50 & 3.00 & 2.75 & 2.65 & 2.12 & 2.39 & 56.84 & 88.00 & 72.42 \\
\hline \multicolumn{10}{|l|}{$\operatorname{LSD}(P \leq 0.05)$} \\
\hline Crops & 0.55 & & & 0.26 & & & ns & & \\
\hline Soil types & 0.95 & & & 0.46 & & & 40.88 & & \\
\hline Interaction & 1.35 & & & ns & & & ns & & \\
\hline
\end{tabular}

Where: $\mathrm{DAE}=$ Days after emergence, MG=Miracle grow, SPM=Sunshine peat moss, GBPH=Garden basic peat humus, $\mathrm{ns=Non-significant} \mathrm{data,} \mathrm{and} \mathrm{LSD=Least} \mathrm{significant} \mathrm{difference}$ 
(15.8) was obtained when crops were grown in GBPH, followed by MG (14.3). In both GBPH and MG, rye had higher NRPP than wheat. The NRPP reduced to minimum of 3.0 in Canyon soil, but no significant differences were observed in the NRPP of the two crops. At 90 DAE, wheat had relatively higher NRPP (15.0) than rye (11.6). The highest NRPP (22.9) were noted when crops were grown in MG, followed by GBPH (20.6), and the NRPP of wheat were higher than rye both soils. The planned mean comparison indicated that crops grown under organic soils produced more NRPP than crops grown under inorganic soils. The NRPP increased with the passage of time (90 $>60>30$ DAE).

\section{Number of tillers plant ${ }^{-1}$}

Rye had significantly higher (6.78) number of tillers plant ${ }^{-1}$ (NTPP) than wheat (3.50) at $90 \mathrm{DAE}$ (Table 10). The highest NTPP (9.00) was noted when crops were grown in MG, being at par with GBPH $\left(8.67 \mathrm{~cm}^{2}\right.$ plant $^{-1}$ day $\left.^{-1}\right)$, and the NTPP of rye was significantly higher than wheat in both soils. The NTPP reduced to minimum (2.33) in Canyon soil; however, there was no difference in NTPP of wheat and rye when grown in Canyon soil. The planned mean comparison indicated that crops grown under organic soils produced more NTPP than crops grown under inorganic soils.

\section{Stem girth}

Wheat had significantly more stem girth $(2.38 \mathrm{~mm})$ than rye $(1.79 \mathrm{~mm})$ at $90 \mathrm{DAE}$ (Table 10$)$. The highest stem girth $(2.68 \mathrm{~mm})$ was noted when crops were grown in AMAS, being at par with MG $(2.55 \mathrm{~mm})$, and the stem girth of wheat was significantly higher than rye in both soils. Interestingly, the planned mean comparison indicated that crops grown under organic soils had less stem girth $(2.18 \mathrm{~mm})$ than crops grown under inorganic soils $(2.39 \mathrm{~mm})$.

\section{Carbon exchange rate}

Rye had relatively higher carbon exchange rate (CER) of 48.30 than wheat $\left(32.99 \mathrm{mmol} \mathrm{m}^{-2} \mathrm{~s}^{-1}\right)$ at $90 \mathrm{DAE}$ (Table 10). The highest CER (90.02 $\left.\mathrm{mmol} \mathrm{m}^{-2} \mathrm{~s}^{-1}\right)$ was noted when crops were grown in Amarillo soil, followed by Canyon soil $\left(54.82 \mathrm{mmol} \mathrm{m}^{-2} \mathrm{~s}^{-1}\right)$. Interestingly, the planned mean comparison indicated that crops grown under organic soils had less CER $\left(24.90 \mathrm{mmol} \mathrm{m}^{-2} \mathrm{~s}^{-1}\right)$ than crops grown under inorganic soils $\left(72.42 \mathrm{mmol} \mathrm{m}^{-2} \mathrm{~s}^{-1}\right)$.

\section{Absolute growth rate}

Absolute growth rate (AGR) was calculated as the ratio of dry matter accumulation per plant per day. The AGR of wheat $\left(1.92 \mathrm{mg}\right.$ plant $^{-1}$ day $\left.^{-1}\right)$ was higher than rye $(1.67 \mathrm{mg}$ plant $^{-1}$ day $^{-1}$ ) at $30 \mathrm{DAE}$ (Table 11). The highest AGR (3.48 $\mathrm{mg}$ plant $^{-1}$ day $^{-1}$ ) was produced when crops were grown in MG, followed GBPH (2.45 mg plant ${ }^{-1}$ day $\left.^{-1}\right)$, and the AGR of wheat was higher than rye in both MG and GBPH. At $60 \mathrm{DAE}$, rye $\left(10.27 \mathrm{mg}\right.$ plant $\left.^{-1} \mathrm{day}^{-1}\right)$ had higher AGR than wheat $\left(8.51 \mathrm{mg}\right.$ plant $\left.^{-1} \mathrm{day}^{-1}\right)$. The highest AGR (20.16 mg plant ${ }^{-1}$ day $\left.^{-1}\right)$ was obtained when crops were grown in MG, being at par with GBPH (19.43 mg plant $^{-1}$ day $\left.^{-1}\right)$, and the AGR of rye at this stage was higher than wheat in both MG and GBPM. At 90 DAE, wheat had higher AGR (30.67 $\mathrm{mg} \mathrm{plant}^{-1}$ day $\left.^{-1}\right)$ than rye $(19.62 \mathrm{mg}$ plant $^{-1}$ day $\left.^{-1}\right)$. The highest AGR (69.82 mg plant ${ }^{-1}$ day $^{-1}$ ) was obtained when crops were grown in MG, followed by GBPH (45.90 mg plant ${ }^{-1}$ day $^{-1}$. The planned mean comparison indicated that crops grown under organic soils had higher AGR than crops grown under inorganic soils. The AGR increased with the passage of time $(90>$ $60>30$ DAE).

\section{Crop growth rate}

Crop growth rate (CGR) was calculated as the ratio of dry matter accumulation per unit ground area per day. The CGR of wheat $\left(0.86 \mathrm{~g} \mathrm{~m}^{-2}\right.$ day $\left.^{-1}\right)$ was higher than rye

Table 11: Absolute growth rate $\left(\mathrm{mg} \mathrm{plant}^{-1}\right.$ day $\left.^{-1}\right)$ of wheat vs. rye grown under different soil types

\begin{tabular}{|c|c|c|c|c|c|c|c|c|c|}
\hline \multirow[t]{2}{*}{ Soil types } & \multicolumn{3}{|c|}{$30 \mathrm{DAE}$} & \multicolumn{3}{|c|}{60 DAE } & \multicolumn{3}{|c|}{90 DAE } \\
\hline & Wheat & Rye & Mean & Wheat & Rye & Mean & Wheat & Rye & Mean \\
\hline Canyon (inorganic) & 0.85 & 0.91 & 0.88 & 1.56 & 1.66 & 1.61 & 13.31 & 3.42 & 8.36 \\
\hline Amarillo (inorganic) & 1.11 & 1.19 & 1.15 & 5.86 & 4.61 & 5.24 & 28.86 & 6.13 & 17.50 \\
\hline MG (organic) & 3.92 & 3.04 & 3.48 & 17.06 & 23.26 & 20.16 & 77.37 & 62.27 & 69.82 \\
\hline SPM (organic) & 2.38 & 1.84 & 2.11 & 9.46 & 8.48 & 8.97 & 8.84 & 5.56 & 7.20 \\
\hline GBPH (organic) & 2.67 & 2.24 & 2.45 & 16.44 & 22.42 & 19.43 & 53.69 & 38.11 & 45.90 \\
\hline Mean & 1.92 & 1.67 & & 8.51 & 10.27 & & 30.67 & 19.62 & \\
\hline \multicolumn{10}{|c|}{ Planned mean comparison } \\
\hline Organic soils & 2.99 & 2.37 & 2.68 & 14.32 & 18.05 & 16.19 & 46.63 & 35.31 & 40.97 \\
\hline Inorganic soils & 0.98 & 1.05 & 1.02 & 3.71 & 3.14 & 3.43 & 21.09 & 4.78 & 12.93 \\
\hline \multicolumn{10}{|l|}{$\operatorname{LSD}(P \leq 0.05)$} \\
\hline Crops & 0.21 & & & 0.83 & & & 3.99 & & \\
\hline Soil types & 0.36 & & & 1.44 & & & 6.90 & & \\
\hline Interaction & 0.50 & & & 2.04 & & & 9.76 & & \\
\hline
\end{tabular}

Where: DAE=Days after emergence, MG=Miracle grow, SPM=Sunshine peat moss, GBPH=Garden basic peat humus, ns=Non-significant data, and LSD=Least significant difference 
Amanullah and Stewart: Soil types influence growth of wheat and rye

Table 12: Crop growth rate $\left(\mathrm{g} \mathrm{m}^{-2}\right.$ day $\left.^{-1}\right)$ of wheat vs. rye grown under different soil types

\begin{tabular}{|c|c|c|c|c|c|c|c|c|c|}
\hline \multirow[t]{2}{*}{ Soil types } & \multicolumn{3}{|c|}{30 DAE } & \multicolumn{3}{|c|}{60 DAE } & \multicolumn{3}{|c|}{$90 \mathrm{DAE}$} \\
\hline & Wheat & Rye & Mean & Wheat & Rye & Mean & Wheat & Rye & Mean \\
\hline Canyon (inorganic) & 0.38 & 0.41 & 0.40 & 0.34 & 0.37 & 0.36 & 3.99 & 1.03 & 2.51 \\
\hline Amarillo (inorganic) & 0.50 & 0.54 & 0.52 & 1.60 & 1.22 & 1.41 & 8.66 & 1.84 & 5.25 \\
\hline MG (organic) & 1.76 & 1.37 & 1.56 & 4.60 & 6.57 & 5.59 & 23.21 & 18.68 & 20.95 \\
\hline SPM (organic) & 1.07 & 0.83 & 0.95 & 2.53 & 2.30 & 2.42 & 2.65 & 1.67 & 2.16 \\
\hline GBPH (organic) & 1.20 & 1.01 & 1.10 & 4.58 & 6.42 & 5.50 & 16.11 & 11.43 & 13.77 \\
\hline Mean & 0.86 & 0.75 & & 2.29 & 2.85 & & 9.20 & 5.89 & \\
\hline \multicolumn{10}{|c|}{ Planned mean comparison } \\
\hline Organic soils & 1.34 & 1.07 & 1.20 & 3.90 & 5.10 & 4.50 & 13.99 & 10.59 & 12.29 \\
\hline Inorganic soils & 0.44 & 0.48 & 0.46 & 0.97 & 0.80 & 0.89 & 6.33 & 1.44 & 3.88 \\
\hline \multicolumn{10}{|l|}{$\operatorname{LSD}(P \leq 0.05)$} \\
\hline Crops & 0.09 & & & 0.26 & & & 1.20 & & \\
\hline Soil types & 0.16 & & & 0.44 & & & 2.07 & & \\
\hline Interaction & 0.23 & & & 0.63 & & & 2.93 & & \\
\hline
\end{tabular}

Where: DAE=Days after emergence, MG=Miracle grow, SPM=Sunshine peat moss, GBPH=Garden basic peat humus, ns=Non-significant data, and LSD=Least significant difference

Table 13: Net assimilation rate $\left(\mathrm{g} \mathrm{m}^{-2}\right.$ day $\left.^{-1}\right)$ of wheat vs. rye grown under different soil types

\begin{tabular}{|c|c|c|c|c|c|c|c|c|c|}
\hline \multirow[t]{2}{*}{ Soil types } & \multicolumn{3}{|c|}{$30 \mathrm{DAE}$} & \multicolumn{3}{|c|}{$60 \mathrm{DAE}$} & \multicolumn{3}{|c|}{$90 \mathrm{DAE}$} \\
\hline & Wheat & Rye & Mean & Wheat & Rye & Mean & Wheat & Rye & Mean \\
\hline Canyon (inorganic) & 117.16 & 116.74 & 116.95 & 23.93 & 35.74 & 29.84 & 31.46 & 9.37 & 20.41 \\
\hline Amarillo (inorganic) & 19.39 & 21.18 & 20.28 & 12.80 & 8.81 & 10.80 & 33.33 & 8.21 & 20.77 \\
\hline MG (organic) & 11.60 & 7.66 & 9.63 & 7.11 & 5.30 & 6.21 & 51.02 & 66.23 & 58.62 \\
\hline SPM (organic) & 14.31 & 11.21 & 12.76 & 7.93 & 6.27 & 7.10 & 8.33 & 6.91 & 7.62 \\
\hline GBPH (organic) & 9.41 & 4.10 & 6.76 & 5.91 & 5.17 & 5.54 & 33.58 & 40.48 & 37.03 \\
\hline Mean & 42.42 & 42.02 & & 12.44 & 13.74 & & 27.59 & 23.12 & \\
\hline \multicolumn{10}{|c|}{ Planned mean comparison } \\
\hline Organic soils & 11.77 & 7.66 & 9.72 & 6.98 & 5.58 & 6.28 & 30.98 & 37.87 & 34.42 \\
\hline Inorganic soils & 68.28 & 68.96 & 68.62 & 18.37 & 22.28 & 20.32 & 32.40 & 8.79 & 20.59 \\
\hline \multicolumn{10}{|l|}{$\operatorname{LSD}(P \leq 0.05)$} \\
\hline Crops & ns & & & ns & & & ns & & \\
\hline Soil types & 27.60 & & & 3.87 & & & 12.43 & & \\
\hline Interaction & ns & & & 5.47 & & & 17.57 & & \\
\hline
\end{tabular}

Where: DAE=Days after emergence, MG=Miracle grow, SPM=Sunshine peat moss, GBPH=Garden basic peat humus, ns=Non-significant data, and LSD=Least significant difference

$\left(0.75 \mathrm{~g} \mathrm{~m}^{-2}\right.$ day $\left.^{-1}\right)$ at $30 \mathrm{DAE}$ (Table 12). The highest CGR $\left(1.56 \mathrm{~g} \mathrm{~m}^{-2} \mathrm{day}^{-1}\right)$ was produced when crops were grown in $\mathrm{MG}$, followed by GBPH $\left(1.10 \mathrm{~g} \mathrm{~m}^{-2} \mathrm{day}^{-1}\right)$, and the CGR of wheat was higher than rye in both MG and GBPH. At 60 DAE, rye $\left(2.85 \mathrm{~g} \mathrm{~m}^{-2}\right.$ day $\left.^{-1}\right)$ had higher CGR than wheat $\left(2.29 \mathrm{~g} \mathrm{~m}^{-2}\right.$ day $\left.^{-1}\right)$. The highest CGR $\left(5.59 \mathrm{~g} \mathrm{~m}^{-2}\right.$ day $\left.^{-1}\right)$ was obtained when crops were grown in MG, being at par with GBPH (5.50 $\left.\mathrm{g} \mathrm{m}^{-2} \mathrm{day}^{-1}\right)$, and the CGR of rye was higher than wheat in both MG and GBPM. At 90 DAE, wheat had higher CGR $\left(9.20 \mathrm{~g} \mathrm{~m}^{-2} \mathrm{day}^{-1}\right)$ than rye $\left(5.89 \mathrm{~g} \mathrm{~m}^{-2} \mathrm{day}^{-1}\right)$. The highest CGR (20.95 $\mathrm{g} \mathrm{m}^{-2}$ day $\left.^{-1}\right)$ was obtained when crops were grown in $\mathrm{MG}$, followed by GBPH $\left(13.77 \mathrm{~g} \mathrm{~m}^{-2} \mathrm{day}^{-1)}\right.$ The planned mean comparison indicated that crops grown under organic soils had higher CGR than crops grown under inorganic soils. The CGR increased with the passage of time $(90>60>30 \mathrm{DAE})$.

\section{Net assimilation rate}

Net assimilation rate (NAR) was calculated as the ratio of dry matter accumulation per unit leaf area per day. The
NAR of wheat $\left(42.42 \mathrm{~g} \mathrm{~m}^{-2}\right.$ day $\left.^{-1}\right)$ and rye $\left(42.02 \mathrm{~g} \mathrm{~m}^{-2}\right.$ day $\left.^{-1}\right)$ was almost the same at $30 \mathrm{DAE}$ (Table 13). The highest NAR $\left(116.95 \mathrm{~g} \mathrm{~m}^{-2}\right.$ day $\left.^{-1}\right)$ was produced when crops were grown in Canyon soil, and there were no significant differences in the NAR of wheat and rye. The minimum NAR $(6.76 \mathrm{~g}$ $\left.\mathrm{m}^{-2} \mathrm{day}^{-1}\right)$ was calculated when crops were grown in GBPH, and wheat $\left(9.41 \mathrm{~g} \mathrm{~m}^{-2} \mathrm{day}^{-1}\right)$ had higher NAR than rye (4.10 $\mathrm{g}$ $\left.\mathrm{m}^{-2} \mathrm{day}^{-1}\right)$. At $60 \mathrm{DAE}$, rye $\left(13.74 \mathrm{~g} \mathrm{~m}^{-2} \mathrm{day}^{-1}\right)$ had higher NAR than wheat $\left(12.44 \mathrm{~g} \mathrm{~m}^{-2} \mathrm{day}^{-1}\right)$, although the differences in the crops were not significant. The highest NAR $(29.84 \mathrm{~g}$ $\mathrm{m}^{-2}$ day $^{-1}$ ) was obtained when crops were grown in Canyon soil, and the NAR of rye was higher than wheat. The NAR reduced to minimum $\left(5.54 \mathrm{~g} \mathrm{~m}^{-2}\right.$ day $\left.^{-1}\right)$ when crops were grown in GBPH, and no significant differences was observed in the NAR of two crops when grown in GBPH. At 90 DAE, wheat had higher NAR (27.59 g $\mathrm{m}^{-2}$ day $\left.^{-1}\right)$ than rye $\left(23.12 \mathrm{~g} \mathrm{~m}^{-2}\right.$ day $\left.^{-1}\right)$, but the differences were not significant. The highest NAR (58.62 $\mathrm{g} \mathrm{m}^{-2}$ day $\left.^{-1}\right)$ was obtained when crops were grown in $M G$, followed by GBPH $\left(37.03 \mathrm{~g} \mathrm{~m}^{-2} \mathrm{day}^{-1}\right)$, and the NAR of rye at this 
stage was higher than wheat in both MG and GBPM. The NAR reduced to minimum $\left(7.62 \mathrm{~g} \mathrm{~m}^{-2} \mathrm{day}^{-1}\right)$ when crops were grown in SPM, and no significant differences was observed in the NAR of wheat $\left(8.33 \mathrm{~g} \mathrm{~m}^{-2} \mathrm{day}^{-1}\right)$ and rye $\left(6.91 \mathrm{~g} \mathrm{~m}^{-2}\right.$ day $\left.^{-1}\right)$ when grown in SPM. The planned mean comparison indicated that crops grown under organic soils had higher NAR than crops grown under inorganic soils at 90 DAE, while organic soils had less NAR than crops grown under inorganic soils at 30 and 60 DAE.

\section{DISCUSSION}

\section{Wheat vs. Rye}

No significant differences were found between wheat and rye for plant height, SER, root length, root to shoot ratio, CER and NAR. Although, earlier research (Amanullah et al., 2011), significant differences were found in plant height of wheat and barley cultivars. The LAPP and LER values were higher for rye than wheat at the two early growth stages (30 and $60 \mathrm{DAE}$ ), and the increase was higher under organic soils. The increase in LAPP and LER of rye over wheat was due to the increase in number of tillers and leaves per plant of rye over wheat. Van den According to Bultynck et al. (2004), crop species with more rapidly elongating leaves showed a faster increase in LER have more biomass allocation to leaf sheaths and less to roots. Boogaard et al. (1996) suggested that a fast LER in wheat was positively correlated with above-ground biomass and grain yield. The SLA and LAR values were also higher for rye than wheat and the increase was more under organic soils. The increase in SLA and LAR of rye over wheat was due to the increase in LAPP of rye over wheat. The NRPP at 30 and 60 DAE, and NTPP at 90 DAE was significantly higher for rye than wheat. The differences in the NRPP and NTPP of the two crops may be due to the difference in their genetic makeup. In our earlier research (Amanullah et al., 2011), we also found significant differences in the number of tillers $\mathrm{m}^{-2}$ of wheat and barley cultivars. Wheat had significantly thicker stem (tiller) girth than rye at 90 DAE. The differences in the stem girths of the two crops may also be due to the difference in the genetic makeup of both crops. Stem girth showed negative relationship with increase in NTPP. Wheat had higher AGR and CGR values than rye at 30 and 90 DAE. However, the AGR and CGR values were higher for rye than wheat at $60 \mathrm{DAE}$. The differences in the AGR and CGR values at different growth stages of both crops was due to the differences in the total dry matter accumulation (Amanullah, 2014).

\section{Organic vs. Inorganic soils}

The four parameters under study viz. shoot to root ratio, stem girth, CER and NAR had higher mean values under inorganic soils as compared to organic soils. Indicating the shoot to root ratio, stem girth, CER and NAR had negative relationship with LAPP, plant height, root length, NRPP, and NTPP. The higher shoot to root ratio (plant height divided by root length) under inorganic soil was attributed to the shorter root lengths under inorganic soils. In contrast, the longer roots of the crops under organic soils at different growth stages, on the other hand reduced the shoot to root ratio (by length) in both crops. Plants under inorganic soils were in stress than plants under organic soil. The stress condition under inorganic soil reduced the root lengths and thereby increased shoot to root ratio under inorganic soil. These results are in conformity with the results obtained by Eghball and Maranville (1993) and Amanullah et al. (2015). The increase in the stem girth under inorganic soils showed negative relationship with increase in NTPP and NRPP. In contrast, both crops under organic soils had significantly more NTPP having thinner stem girths. Crops with higher CER under inorganic soil than organic soils was not too much clear and we recommend further research to confirm the difference in CER of crops under different soil types. The increase in NAR under inorganic soils was due to the decrease in LAPP, leaf area index, CGR and total dry matter accumulation under inorganic soils (Amanullah, 2014). Amanullah and Stewart (2013) reported that NAR of oats had negative relationship with increase in leaf area index and positive relationship with increase in CGR.

The LAPP, LER, SLA, LAR, plant height, SER, root length, NRPP, NTPP, AGR and CGR were significantly better (higher) under organic soils than inorganic soils. Improvement in all these parameters under organic soils probably may be due to high water holding capacity; lower bulk density and better physical soil conditions (Cowan, online) as well as carry more nitrogen (Pedosphere, 2001) in organic soils. Moreover, the published research from this study confirmed that water use efficiency, dry matter accumulation in roots and shoots was significantly higher in both crops under organic soils (Amanullah, 2014) that had positive impact on crop growth analysis. On the other hand, the restricted root and shoot development of both crops and less water use efficiency under inorganic soils (Amanullah, 2014) had adverse effects on the growth analysis of both crops. Amanullah and Stewart (2013) suggested that increase in total dry matter accumulation per plant had positive relationship with AGR, CGR and NAR in oats.

\section{CONCLUSIONS}

Wheat and rye responded differently in growth under different soil types. Both crops had better performance 
in terms of higher leaf area per plant, leaf area expansion rate, specific leaf area, leaf area ratio, plant height, stem elongation rate, root length, number of roots per plant, number of tillers per plant, absolute growth rate and crop growth rate under organic soils as compared with inorganic soils at different growth stages. Interestingly, the stem girth, carbon exchange rate and net assimilation rate in both crops was declined under organic soils as compared with inorganic soils. Further research is needed to confirm the reduction in stem girth, carbon exchange rate and net assimilation rate under inorganic soils than organic soils.

\section{ACKNOWLEDGMENTS}

Prof. Dr. Paigham Shah, The University of Agriculture Peshawar, Pakistan for the statistical analysis of the data, and Dryland Agriculture Institute, West Texas A\&M University, Texas, United States for technical support are greatly acknowledged.

\section{Funding}

Financial support from the Higher Education Commission, Islamabad, Pakistan is gratefully acknowledged.

\section{Author contributions}

A. designed the study, took data, did the analysis, and wrote this paper. B. A. S. supervised this research work at the green house in WTAMU, Texas, USA.

\section{REFERENCES}

Amanullah, B. A. Stewart and Hidayatullah. 2015. Cool Season C3Grasses (Wheat, Rye, Barley, and Oats) differ in shoot: Root ratio when applied with different NPK sources. J. Plant Nutr. 38:189-201.

Amanullah. 2014. Wheat and rye differ in drymatter partitioning, hootroot ratio and water use effi ciency under organic and inorganic soils. J. Plant Nutr. 37: 1885-1897.

Amanullah, J and B. A. Stewart. 2013. Dry matter partitioning, growth analysis and water use effi ciency response of oats (Avena sativa L.) to excessive nitrogen and phosphorus application. J. Agric.Sci. Technol. 15: 479-489.

Amanullah, S. Khan, S. K. Khalil, A. Jan, A. Z. Khan and K. Nawab. 2011. Performance of high yielding wheat and barley cultivars under moisture stress. Pak. J. Bot. 43:2143-2145.

Bultynck, L., M. W. T. Seege, M. Schortemeyer, P. Poot and H. Lambers. 2004. Individual leaf elongation to whole shoot leaf area expansion: A comparison of three Aegilops and two Triticum species. Ann. Bot. 94:99-108.

Craufurd, P. Q., T. R. Wheeler, R. H. Ellis, R. J. Summerfi eld and J. H. Williams. 1999. Effect of temperature and water defi cit on water use effi ciency, carbon isotope discrimination and specifi c leaf area in peanut. Crop Sci. 39: 136-142.

Eghball, B and J. W. Maranville. 1993. Root development and nitrogen infl ux of corn genotypes grown under combined drought and nitrogen stresses. Agronomy Journal 85: 147-152.

Kurtar, E. S and A. K. Ayan. 2004. Organic farming and condition. J. Fac. Agric. OMÜ Turkey. 19: 56-64.

Pedosphere.com. 2001. Searchable Keys to Soil Taxonomy. $8^{\text {th }}$ ed. Available from: http://www.pedosphere.ca/resources/sg usa/. [Last accessed on 2014 June 06].

Plaster, E.J. 2009. Plant nutrition. In: Soil Science and Management. $5^{\text {th }}$ ed. Delmar Cengage learning, NY, USA. p. 259-268.

Steel, R. G. D and J. H. Torrie. 1980. Principles and Procedures of Statistics. McGraw-Hill, NY, United States.

Van den Boogaard, R, E. J. Veneklaas, J. Peacock and H. Lambers.1996. Yield and water use of wheat (Triticum aestivum L.) cultivars in a Mediterranean environment: Effects of water availability and sowing density. Plant. Soil. 181: 251-262.

Zengin, M. 2007. Organic Agriculture. Hasad Publish, Istanbul, Turkey. 